\title{
Optimization of Callogenesis/Caulogenesis Induction Protocol in Saffron Plant (Crocus sativus L.) Using
} Response Surface Methodology

\author{
Chaimae Slimani ${ }^{1,2, *}$, Younes El Goumi ${ }^{1}$, Chaimae Rais ${ }^{3}$, Lahsen El Ghadraoui ${ }^{2}$, Meryem Benjelloun ${ }^{2}$, \\ Abderrahim Lazraq ${ }^{2}$ \\ 1 Phyto-Biotechnology laboratory, National Agency of Medicinal and Aromatic Plants, Taounate, 34025, Morocco; \\ elgoumiyounes@hotmail.com (Y.E.G.); \\ 2 Laboratory of Functional Ecology and Environmental Engineering, Faculty of Science and Technology, Sidi Mohamed \\ Ben Abdellah University-Fez. 2202, Morocco; lahelghadraoui@yahoo.fr (L.E.G.); Mery_benjelloun@hotmail.com \\ (M.B.); abderrahim.lazraq@usmba.ac.ma (A.L.); \\ 3 Laboratory of Botany, National Agency of Medicinal and Aromatic Plants, 34025 Taounate, Morocco; \\ raischaimae18@gmail.com (C.R.) \\ * Correspondence: chaimae.slimani94@gmail.com (C.S.);
}

Scopus Author ID 0000-0002-5549-4496

Received: 10.08.2021; Revised: 12.09.2021; Accepted: 18.09.2021; Published: 16.10.2021

Abstract: The Crocus sativus, an endangered medicinal and aromatic plant in Morocco, has a low propagation rate in natural conditions and, therefore, an efficient method for in vitro propagation is required. This study investigated the effects of various hormones on the induction of callogenesis and callogenesis in C. sativus corms using the Box-Behnken experimental design. The best shoot formation was obtained with Murashige and Skoog fortified with $3 \mathrm{mg} / \mathrm{L}$ 6-Benzylaminopurine. On the other hand, callus formation was obtained with $3 \mathrm{mg} / \mathrm{L} 1$-Naphthaleneacetic Acid or $3 \mathrm{mg} / \mathrm{L} \mathrm{2,4-}$ Dichlorophenoxyacetic Acid. However, a combination of $3 \mathrm{mg} / \mathrm{L}$ 6-Benzylaminopurine, $1.056 \mathrm{mg} / \mathrm{L}$ Indole Butyric Acid, and $3 \mathrm{mg} / \mathrm{L}$ 2,4-Dichlorophenoxyacetic Acid allows 50\% caulogenesis and 60\% callogenesis. The in vitro regeneration system could be utilized for both conservation and largescale multiplication of Crocus sativus corms.

Keywords: Crocus sativus; response surface methodology; Box-Behnken design; caulogenesis; callogenesis.

(C) 2021 by the authors. This article is an open-access article distributed under the terms and conditions of the Creative Commons Attribution (CC BY) license (https://creativecommons.org/licenses/by/4.0/).

\section{Introduction}

Saffron (Crocus sativus L.), a local product of the Anti-Atlas marocain, is well known as the most expensive spice in the world. It is certainly the most interesting and attractive species for the properties of its dry stigmas, including its coloring power, bitter taste, and aromatic potency [1,2]. Saffron contains at least 150 volatile and non-volatile compounds. Quality of which involves three main secondary metabolites; crocin, picrocrocin, and safranal, respectively responsible for its color, taste, and aroma [3,4].

Dry stigmas of $C$. sativus are used in food, cosmetics, perfume, and coloring industries [5]. Various studies have highlighted the antidiabetic, antidepressant, anti-inflammatory, antioxidant, and anticancer activities of saffron [6-12].

C. sativus is a sterile triploid geophyte $(2 \mathrm{n}=3 \mathrm{x}=24)$ propagated vegetatively by corms. The rate of natural saffron propagation is relatively low, which currently constitutes a real constraint for extending this culture. Typically only four to five cormlets per mother corm per 
season are produced in saffron fields through natural breeding. These low multiplication rates of cormlets, aggravated by problems of fungal infestation, limit the availability of adequate plant material and considerably reduce saffron productivity [13-15].

In addition to conventional propagation methods, biotechnological approaches such as in vitro culture methods contribute significantly to the spread of economically important species [16,17]. Micropropagation is an in vitro plant cloning technique to produce plants in large quantities [18-20]. This technique refers to the culture of tissues of the selected plants that are grown in an aseptic condition on a medium containing macro and micronutrients to produce disease-free and true-to-type plants [21-23].

For this purpose, it is necessary to have an in vitro propagation protocol to preserve the germ-plasm of $C$. sativus $\mathrm{L}$. in Morocco. For this, the present study's objective is to validate a suitable hormonal combination for the induction of callogenesis/caulogenesis of Taliouine saffron.

\section{Materials and Methods}

\subsection{Plant material.}

Samples of healthy $C$. sativus corms were provided by one of the main saffronproducing villages (Taliouine) in Taroudant Province, Morocco, during February 2018. The corms measure 1.5 to $2.5 \mathrm{~cm}$ in diameter.

\subsection{Disinfection of corms.}

After removing the protective tunic, corms were thoroughly washed with running tap water for $10 \mathrm{~min}$ to remove the coating layer of microorganisms ubiquitously found on them. Corms were superficially disinfected with $70 \%$ alcohol for threes, then immersed in a $4.5 \%$ sodium hypochlorite solution with $0.3 \%$ Tween 20 for $15 \mathrm{~min}$ and rinsed four times with sterile distilled water 3 min each. The disinfection was carried out under a laminar flow hood.

\subsection{Preparation of culture medium.}

The culture medium used was MS medium Murashige et Skoog [24] enriched with growth hormones, supplemented with sucrose at $30 \mathrm{~g} / \mathrm{L}$, and solidified with agar-agar at $9 \mathrm{~g} / \mathrm{L}$. Medium's $\mathrm{pH}$ was adjusted between 5.6 and 5.8 before autoclaving at $120{ }^{\circ} \mathrm{C}$ for $20 \mathrm{~min}$ and under 1 bar pressure.

\subsection{Cultivation and transplanting.}

An optimization plan was established using 2 cytokinins, Kinetin (Kn), 6Benzylaminopurine (BAP) and 3 auxins, 1-Naphthaleneacetic Acid (ANA), Indole Butyric Acid (IBA), 2,4-Dichlorophenoxyacetic Acid (2,4-D) with different hormonal combinations to predict the most effective combination of hormones for callogenesis and caulogenesis induction. The disinfected corms were dried with sterile paper and cut into small pieces containing apical nodes and meristematic lateral (Figure 1), then introduced aseptically into Petri dishes containing $20 \mathrm{~mL}$ of MS at a rate of five explants per dish. A number of 920 explants were used for callogenesis and caulogenesis induction. The cultures were placed in a conditioned room (phytotron) under a luminous intensity of $1600 \mathrm{~W}$ provided by Sylvania fluorescent tubes. The temperature was maintained at $22 \pm 2{ }^{\circ} \mathrm{C}$. 


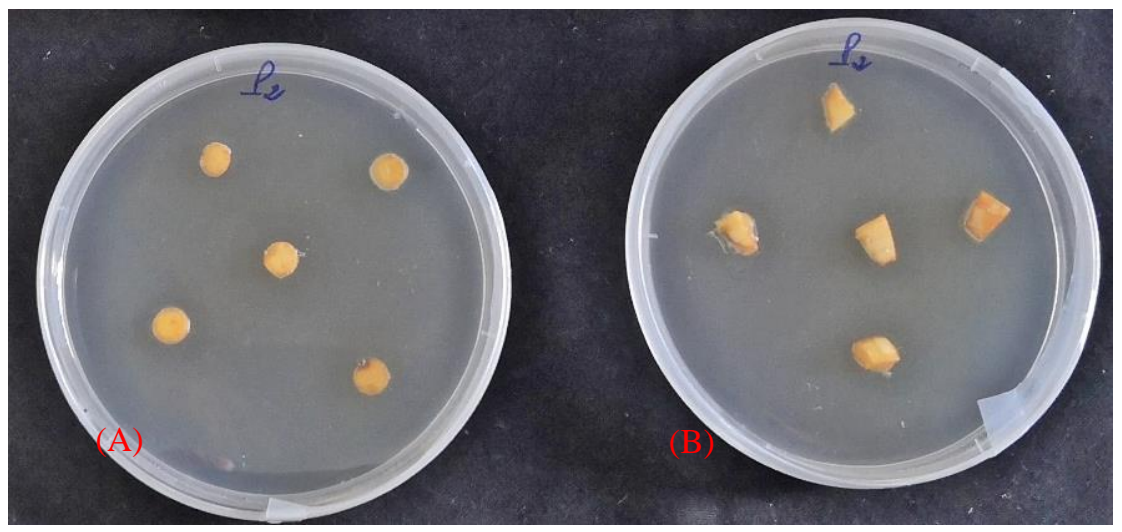

Figure 1. Cultivation of $C$. sativus explants.

\subsection{Experimental Design.}

Response Surface Methodology (RMS) is a technique that objective is to quantitatively determine response variation as a function of significant influence factors. Screening plans had only two levels of study per factor, and the mathematical models used were first-degree (with or without interactions) for each factor. These plans sometimes lead to simple modeling [25]. However, there are many cases where it is necessary to have good modeling of the phenomena studied and where it is necessary to move to mathematical models of the second degree. The response surface planes are then used. These plans were applied as a result of the screening study because they only use factors previously considered influential [26,27].

Quadratic Box-Behnken experimental design was used to study the effect of hormones on the induction of caulogenesis and callogenesis in $C$. sativus (responses). The design was composed of three levels (low, medium, and high, coded $-1,0$, and +1 ) and a total of 46 combinations were performed in duplicate to optimize the factor level (Kn, BAP, ANA, IBA, 2,4-D). These were noted $\mathrm{X}_{1}, \mathrm{X}_{2}, \mathrm{X}_{3}, \mathrm{X}_{4}$, and $\mathrm{X}_{5}$, respectively. The choice of factor levels consists of choosing each factor's high and low levels (Table 1). The experimental design matrix of the Box-Behnken model was presented in Table 2.

The choice of factors has been taken into account based on previous studies in C. sativus species [28-32].

Table 1. Factors and their actual and coded levels of the optimization study.

\begin{tabular}{l|l|l|l|l|l|l|l} 
Real factor & Coded factor & Unit & Center & Variation step & \multicolumn{3}{|l}{ Actual level of coded factors } \\
\cline { 6 - 9 } & & & & & -1 & 0 & +1 \\
\hline Kn & $\mathrm{X}_{1}$ & $\mathrm{mg} / \mathrm{L}$ & 1.5 & 1.5 & 0 & 1.5 & 3 \\
\hline BAP & $\mathrm{X}_{2}$ & $\mathrm{mg} / \mathrm{L}$ & 1.5 & 1.5 & 0 & 1.5 & 3 \\
\hline ANA & $\mathrm{X}_{3}$ & $\mathrm{mg} / \mathrm{L}$ & 1.5 & 1.5 & 0 & 1.5 & 3 \\
\hline IBA & $\mathrm{X}_{4}$ & $\mathrm{mg} / \mathrm{L}$ & 1.5 & 1.5 & 0 & 1.5 & 3 \\
\hline $2,4 \mathrm{D}$ & $\mathrm{X}_{5}$ & $\mathrm{mg} / \mathrm{L}$ & 1.5 & 1.5 & 0 & 1.5 & 3
\end{tabular}

\subsection{Mathematical model and statistical analysis.}

The mathematical model postulated and used for composite designs was a seconddegree model in which the coefficient $\mathrm{R}^{2}$ has been determined. Response surface method uses polynomial models of second degree [33]. Callogenesis and caulogenesis Induction (Y) depends on these factors above. Resulting quadratic mathematical model was a polynomial of order 2: 
$E q$ (A.1) $Y=a_{0}+a_{1} X_{1}+a_{2} X_{2}+a_{3} X_{3}+a_{4} X_{4}+a_{5} X_{5}+a_{12} X_{1} X_{2}+a_{13} X_{1} X_{3}+a_{14}$ $X_{1} X_{4}+a_{15} X_{1} X_{5}+a_{23} X_{2} X_{3}+a_{24} X_{2} X_{4}+a_{25} X_{2} X_{5}+a_{34} X_{3} X_{4}+a_{35} X_{3} X_{5}+a_{45} X_{4} X_{5}+a_{11} X_{1} X_{1}$ $+A_{22} X_{2} X_{2}+a_{33} X_{3} X_{3}+a_{44} X_{4} X_{4}+a_{55} X_{5} X_{5}+\varepsilon$

With:

$\mathrm{Y}$ : induction (response); $\left(\mathrm{X}_{1}, \mathrm{X}_{2}, \mathrm{X}_{3}, \mathrm{X}_{4}, \mathrm{X}_{5}\right)$ : factors taken into account; $\mathrm{a}_{\mathrm{i}}\left(\mathrm{a}_{0}, \mathrm{a}_{1}, \mathrm{a}_{2}\right.$, $\mathrm{a}_{3}, \mathrm{a}_{4}, \mathrm{a}_{5}$ ): factor coefficients; $\varepsilon$ : error term.

This study was conducted using JMP SAS Software (JMP®, version <14> SAS Institute Inc.). The mathematical models obtained were validated by analyzing variance test (ANOVA) and file test (linear model by least-square standard). The average responses were compared by Tukey's Honestly Significant Difference (HSD) test at the risk of 0.05 error.

Table 2. Experimental matrix of the effect of hormones on induction.

\begin{tabular}{|c|c|c|c|c|c|}
\hline ID & Kn (mg/L) & BAP $(\mathrm{mg} / \mathrm{L})$ & ANA (mg/L) & IBA $(\mathrm{mg} / \mathrm{L})$ & $2,4-\mathrm{D}(\mathrm{mg} / \mathrm{L})$ \\
\hline 1 & 1,5 & 0 & 0 & 1,5 & 1,5 \\
\hline 2 & 1,5 & 1,5 & 3 & 0 & 1,5 \\
\hline 3 & 1,5 & 1,5 & 1,5 & 1,5 & 1,5 \\
\hline 4 & 1,5 & 3 & 3 & 1,5 & 1,5 \\
\hline 5 & 1,5 & 0 & 1,5 & 0 & 1,5 \\
\hline 6 & 1,5 & 1,5 & 3 & 3 & 1,5 \\
\hline 7 & 3 & 1,5 & 1,5 & 3 & 1,5 \\
\hline 8 & 0 & 1,5 & 1,5 & 1,5 & 3 \\
\hline 9 & 1,5 & 3 & 1,5 & 3 & 1,5 \\
\hline 10 & 0 & 1,5 & 3 & 1,5 & 1,5 \\
\hline 11 & 3 & 1,5 & 3 & 1,5 & 1,5 \\
\hline 12 & 0 & 1,5 & 0 & 1,5 & 1,5 \\
\hline 13 & 3 & 0 & 1,5 & 1,5 & 1,5 \\
\hline 14 & 3 & 1,5 & 0 & 1,5 & 1,5 \\
\hline 15 & 1,5 & 0 & 1,5 & 1,5 & 0 \\
\hline 16 & 1,5 & 1,5 & 0 & 0 & 1,5 \\
\hline 17 & 1,5 & 3 & 1,5 & 1,5 & 3 \\
\hline 18 & 1,5 & 1,5 & 1,5 & 1,5 & 1,5 \\
\hline 19 & 3 & 1,5 & 1,5 & 0 & 1,5 \\
\hline 20 & 1,5 & 1,5 & 0 & 1,5 & 0 \\
\hline 21 & 0 & 3 & 1,5 & 1,5 & 1,5 \\
\hline 22 & 1,5 & 1,5 & 1,5 & 1,5 & 1,5 \\
\hline 23 & 1,5 & 1,5 & 1,5 & 1,5 & 1,5 \\
\hline 24 & 1,5 & 3 & 1,5 & 1,5 & 0 \\
\hline 25 & 1,5 & 1,5 & 3 & 1,5 & 3 \\
\hline 26 & 0 & 0 & 1,5 & 1,5 & 1,5 \\
\hline 27 & 1,5 & 1,5 & 1,5 & 3 & 0 \\
\hline 28 & 0 & 1,5 & 1,5 & 3 & 1,5 \\
\hline 29 & 1,5 & 1,5 & 1,5 & 0 & 0 \\
\hline 30 & 3 & 1,5 & 1,5 & 1,5 & 0 \\
\hline 31 & 1,5 & 1,5 & 1,5 & 1,5 & 1,5 \\
\hline 32 & 1,5 & 1,5 & 3 & 1,5 & 0 \\
\hline 33 & 1,5 & 1,5 & 0 & 3 & 1,5 \\
\hline 34 & 1,5 & 0 & 1,5 & 3 & 1,5 \\
\hline 35 & 3 & 1,5 & 1,5 & 1,5 & 3 \\
\hline 36 & 1,5 & 3 & 1,5 & 0 & 1,5 \\
\hline 37 & 1,5 & 1,5 & 1,5 & 1,5 & 1,5 \\
\hline 38 & 1,5 & 0 & 3 & 1,5 & 1,5 \\
\hline 39 & 0 & 1,5 & 1,5 & 1,5 & 0 \\
\hline 40 & 1,5 & 3 & 0 & 1,5 & 1,5 \\
\hline 41 & 1,5 & 0 & 1,5 & 1,5 & 3 \\
\hline 42 & 3 & 3 & 1,5 & 1,5 & 1,5 \\
\hline
\end{tabular}




\begin{tabular}{c|c|c|c|c|c}
\hline \multicolumn{1}{|c|}{} & $\mathbf{K n}(\mathbf{m g} / \mathbf{L})$ & $\mathbf{B A P}(\mathbf{m g} / \mathbf{L})$ & ANA $(\mathbf{m g} / \mathbf{L})$ & $\mathbf{I B A}(\mathbf{m g} / \mathbf{L})$ & $\mathbf{2 , 4 - D}(\mathbf{m g} / \mathbf{L})$ \\
\hline $\mathbf{4 3}$ & 1,5 & 1,5 & 1,5 & 3 & 3 \\
\hline $\mathbf{4 4}$ & 1,5 & 1,5 & 1,5 & 0 & 3 \\
\hline $\mathbf{4 5}$ & 1,5 & 1,5 & 0 & 1,5 & 3 \\
\hline $\mathbf{4 6}$ & 0 & 1,5 & 1,5 & 0 & 1,5
\end{tabular}

\section{Results and Discussion}

\subsection{Experimental design.}

Effect summary of phytohormones used for caulogenesis and callogenesis induction is shown in Table 3. Results show that the effective model is significant for BAP, $\mathrm{BAP}^{2}$, and the ANA*2,4-D interaction since the probability of significance of the p-value risk is inferior to 0.05 .

Table 3. Effects summary of phytohormones.

\begin{tabular}{|c|c|c|c|}
\hline Source & Log Worth & & P Value \\
\hline $\operatorname{BAP}(0,3)$ & 4,031 & \begin{tabular}{ll|l:l:l}
1 & $\vdots$ & $\vdots$ & $\vdots$
\end{tabular} & 0,00009 \\
\hline BAP*BAP & 2,262 & 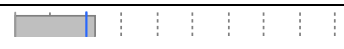 & 0,00547 \\
\hline $\begin{array}{l}\text { ANA*2,4- } \\
\text { D }\end{array}$ & 1,395 & 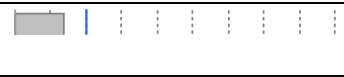 & 0,04023 \\
\hline $2,4-\mathrm{D}(0,3)$ & 1,033 & 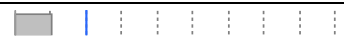 & 0,09278 \\
\hline $\mathrm{Kn} * \mathrm{BAP}$ & 0,902 & 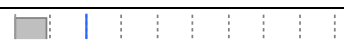 & 0,12518 \\
\hline $\operatorname{ANA}(0,3)$ & 0,771 & 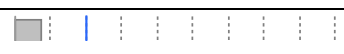 & 0,16945 \\
\hline IBA*IBA & 0,736 & 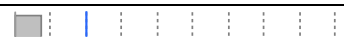 & 0,18378 \\
\hline $\mathrm{Kn} * 2,4-\mathrm{D}$ & 0,730 & 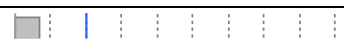 & 0,18600 \\
\hline $\begin{array}{l}\text { BAP*2,4- } \\
\text { D }\end{array}$ & 0,730 & 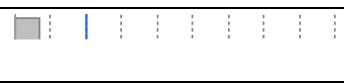 & 0,18600 \\
\hline $\begin{array}{l}\text { ANA*AN } \\
\text { A }\end{array}$ & 0,695 & $\begin{array}{lllllllll} & \square\end{array}$ & 0,20168 \\
\hline Kn*ANA & 0,594 & 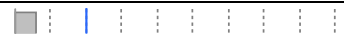 & 0,25495 \\
\hline ANA*IBA & 0,485 & $\begin{array}{l}\square \\
\end{array}$ & 0,32751 \\
\hline $\operatorname{IBA}(0,3)$ & 0,428 & 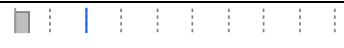 & 0,37328 \\
\hline $\mathrm{Kn} * \mathrm{IBA}$ & 0,384 & 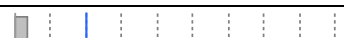 & 0,41314 \\
\hline $\begin{array}{l}\text { IBA*2,4- } \\
\text { D }\end{array}$ & 0,299 & 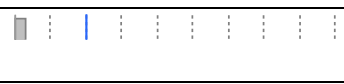 & 0,50279 \\
\hline BAP*IBA & 0,291 & 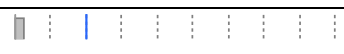 & 0,51163 \\
\hline $\mathrm{Kn}(0,3)$ & 0,248 & 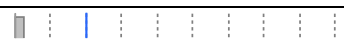 & 0,56540 \\
\hline $\mathrm{Kn} * \mathrm{Kn}$ & 0,203 & 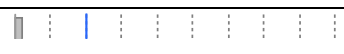 & 0,62720 \\
\hline $\begin{array}{l}2,4-\mathrm{D} * 2,4- \\
\mathrm{D}\end{array}$ & 0,203 & 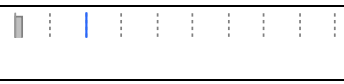 & 0,62720 \\
\hline $\begin{array}{l}\mathrm{BAP} * \mathrm{AN} \\
\mathrm{A}\end{array}$ & 0,184 & $\begin{array}{lllllllllll} & \vdots & 1 & \vdots & \vdots & \vdots & \vdots & \vdots & \vdots & \vdots\end{array}$ & 0,65424 \\
\hline
\end{tabular}

\subsection{Model validation.}

The coefficient of determination, $\mathrm{R}^{2}$, allowed to quantify the quality of the model used in this study. The model meaning is determined by the values of $\mathrm{R}^{2}$ and $\mathrm{p}$-values. When the $\mathrm{R}^{2}$ is larger, and the p-value is smaller, the model is more significant [34,35].

The $\mathrm{R}^{2}$ are in order of 0.632 and 0.474 with adjusted $\mathrm{R}^{2}$ equal to 0.054 and 0.339 , respectively, for caulogenesis and callogenesis (Table 4). As for the theoretical values predicted by the model, the p-values of caulogenesis and callogenesis are 0.035 and 0.309 , respectively (Table 5). The results allowed us to conclude that this model is more applicable for caulogenesis. 
Table 4. Coefficient of determination of caulogenesis (A) and callogenesis (B).

\begin{tabular}{c|c} 
(A) & \\
\hline RSquare & 0,632885 \\
\hline RSquare Adj & 0,339193 \\
\hline Root Mean Square Error & 11,03026 \\
\hline Mean of Response & 32,28261 \\
\hline Observations (or Sum Wgts) & 46
\end{tabular}

\begin{tabular}{c|c} 
(B) & \\
\hline RSquare & 0,47475 \\
\hline RSquare Adj & 0,054551 \\
\hline Root Mean Square Error & 15,01943 \\
\hline Mean of Response & 17,3913 \\
\hline Observations (or Sum Wgts) & 46
\end{tabular}

Table 5. Variance Analysis of Caulogenesis (A) and Callogenesis (B).

\begin{tabular}{c|c|c|c|c}
$(\mathbf{A})$ & & & & \\
\hline Source & DF & $\begin{array}{c}\text { Sum of } \\
\text { Squares }\end{array}$ & $\begin{array}{c}\text { Mean } \\
\text { Square }\end{array}$ & F Ratio \\
\hline Model & 20 & 5243,6594 & 262,183 & 2,1549 \\
\hline Error & 25 & 3041,6667 & 121,667 & $\begin{array}{c}\text { Prob > } \\
\text { F }\end{array}$ \\
\hline $\begin{array}{c}\text { C. } \\
\text { Total }\end{array}$ & 45 & 8285,3261 & & $0,0352^{*}$
\end{tabular}

\begin{tabular}{c|c|c|c|c}
$(\mathbf{B})$ & DF & $\begin{array}{c}\text { Sum of } \\
\text { Squares }\end{array}$ & $\begin{array}{c}\text { Mean } \\
\text { Square }\end{array}$ & F Ratio \\
\hline Model & 20 & 5097,373 & 254,869 & 1,1298 \\
\hline Error & 25 & 5639,583 & 225,583 & $\begin{array}{c}\text { Prob > } \\
\text { F }\end{array}$ \\
\hline $\begin{array}{c}\text { C. } \\
\text { Total }\end{array}$ & 45 & 10736,957 & & 0,3818
\end{tabular}

Regarding the lack of fit test, the results indicate that this value is not significant for caulogenesis and callogenesis (Prob> F =0.303, Prob> F =0.309). This means that the data are adjusted, so the model is acceptable (Table 6).

Table 6. Lack of fit of the experimental model for caulogenesis (A) and callogenesis (B) responses.

\begin{tabular}{l|r|r|r|r}
\multicolumn{1}{c|}{ Source } & DF & $\begin{array}{c}\text { Sum of } \\
\text { Squares }\end{array}$ & $\begin{array}{c}\text { Mean } \\
\text { Square }\end{array}$ & F Ratio \\
\hline $\begin{array}{l}\text { Lack Of } \\
\text { Fit }\end{array}$ & 20 & 2641,6667 & 132,083 & 1,6510 \\
\hline $\begin{array}{l}\text { Pure } \\
\text { Error }\end{array}$ & 5 & 400,0000 & 80,000 & Prob > \\
\hline $\begin{array}{l}\text { Total } \\
\text { Error }\end{array}$ & 25 & 3041,6667 & & 0,3036 \\
\hline & & & & $\mathbf{F}$ \\
\hline & & & & $\begin{array}{r}\text { Max } \\
\mathbf{R S q}\end{array}$ \\
\hline & & & & 0,9517
\end{tabular}

\begin{tabular}{c|c|r|r|r}
$(\mathbf{B})$ & & & & \\
\hline Source & DF & $\begin{array}{c}\text { Sum of } \\
\text { Squares }\end{array}$ & $\begin{array}{c}\text { Mean } \\
\text { Square }\end{array}$ & F Ratio \\
\hline Lack Of Fit & 20 & 4889,5833 & 244,479 & 1,6299 \\
\hline Pure Error & 5 & 750,0000 & 150,000 & $\begin{array}{r}\text { Prob > } \\
\mathbf{F}\end{array}$ \\
\hline Total Error & 25 & 5639,5833 & & 0,3092 \\
\hline & & & & $\begin{array}{r}\text { Max } \\
\text { RSq }\end{array}$ \\
\hline & & & & 0,9301
\end{tabular}

3.3. Induction of caulogenesis/callogenesis in C. sativus.

3.3.1. Caulogenesis.

\subsubsection{Effect test.}

Results show the model coefficients in which each is associated with its value, standard error, t-student, and p-value. The effects of BAP and $\mathrm{BAP}^{2}$ are significant (Table 7).

Quadratic equation for predicting the optimal point was obtained according to BoxBehnken design and input variables, then the empirical relationship between the response and the independent variables. The quadratic model that summarizes all the tests representing caulogenesis induction for $C$. sativus is as follows:

Eq (A.2) $Y=40+0.625\left(\mathrm{X}_{1}\right)+12.812\left(\mathrm{X}_{2}\right)+0.625\left(\mathrm{X}_{3}\right)+2.5\left(\mathrm{X}_{4}\right)-4.062\left(\mathrm{X}_{5}\right)-8.75\left(\mathrm{X}_{1} \mathrm{X}_{2}\right)-$

$2.5\left(\mathrm{X}_{1} \mathrm{X}_{3}\right)-2.5\left(\mathrm{X}_{2} \mathrm{X}_{3}\right)-1.25\left(\mathrm{X}_{1} \mathrm{X}_{4}\right)+2.5\left(\mathrm{X}_{2} \mathrm{X}_{4}\right)-2.5\left(\mathrm{X}_{3} \mathrm{X}_{4}\right)-7.5\left(\mathrm{X}_{1} \mathrm{X}_{5}\right)+7.5\left(\mathrm{X}_{2} \mathrm{X}_{5}\right)+3.75\left(\mathrm{X}_{4} \mathrm{X}_{5}\right)-$

$$
0.937\left(\mathrm{X}_{1}^{2}\right)-11.354\left(\mathrm{X}_{2}^{2}\right)-4.270\left(\mathrm{X}_{3}^{2}\right)-5.104\left(\mathrm{X}_{4}{ }^{2}\right)-0.520\left(\mathrm{X}_{5}\right) \text {. }
$$

The simplified equation is represented according to the following formula:

$$
\text { Eq (A.3) } \mathrm{Y}=40+12.812\left(\mathrm{X}_{2}\right)-11.354\left(\mathrm{X}_{2}^{2}\right) \text {. }
$$


Table 7. Effect of the experimental model coefficients on caulogenesis.

\begin{tabular}{c|c|c|c|c} 
Term & Estimate & Std Error & t Ratio & Prob $>|\mathbf{t}|$ \\
\hline Intercept & 40 & 4,503085 & 8,88 & $<, 0001^{*}$ \\
\hline Kn(0,3) & 0,625 & 2,757565 & 0,23 & 0,8225 \\
\hline BAP(0,3) & 12,8125 & 2,757565 & 4,65 & $<, 0001^{*}$ \\
\hline ANA(0,3) & 0,625 & 2,757565 & 0,23 & 0,8225 \\
\hline IBA(0,3) & 2,5 & 2,757565 & 0,91 & 0,3733 \\
\hline $2,4-D(0,3)$ & $-4,0625$ & 2,757565 & $-1,47$ & 0,1532 \\
\hline Kn*BAP & $-8,75$ & 5,515131 & $-1,59$ & 0,1252 \\
\hline Kn*ANA & $-2,5$ & 5,515131 & $-0,45$ & 0,6542 \\
\hline BAP*ANA & $-2,5$ & 5,515131 & $-0,45$ & 0,6542 \\
\hline Kn*IBA & $-1,25$ & 5,515131 & $-0,23$ & 0,8225 \\
\hline BAP*IBA & 2,5 & 5,515131 & 0,45 & 0,6542 \\
\hline ANA*IBA & $-2,5$ & 5,515131 & $-0,45$ & 0,6542 \\
\hline Kn*2,4-D & $-7,5$ & 5,515131 & $-1,36$ & 0,1860 \\
\hline BAP*2,4-D & 7,5 & 5,515131 & 1,36 & 0,1860 \\
\hline ANA*2,4-D & 0 & 5,515131 & 0,00 & 1,0000 \\
\hline IBA*2,4-D & 3,75 & 5,515131 & 0,68 & 0,5028 \\
\hline Kn*Kn & $-0,9375$ & 3,733761 & $-0,25$ & 0,8038 \\
\hline BAP*BAP & $-11,35417$ & 3,733761 & $-3,04$ & $0,0055^{*}$ \\
\hline ANA*ANA & $-4,270833$ & 3,733761 & $-1,14$ & 0,2635 \\
\hline IBA*IBA & $-5,104167$ & 3,733761 & $-1,37$ & 0,1838 \\
\hline 2,4-D*2,4-D & $-0,520833$ & 3,733761 & $-0,14$ & 0,8902
\end{tabular}

3.3.1.2. Evaluation of phytohormones effects.

\subsubsection{Effect of $\mathrm{kn} * \mathrm{BAP}$ interaction on caulogenesis.}

Response surfaces were developed by software thanks to the mathematical model obtained. This allowed for predictions in the field of study.

The analysis of response surface for the interaction of two cytokinins (Kn*BAP) and their effect on caulogenesis shows a response that can reach $45 \%$ using $3 \mathrm{mg} / \mathrm{L}$ of BAP with the absence of $\mathrm{Kn}$. Beyond this range, a negative effect has been observed on caulogenesis induction. Low concentrations of BAP may decrease the response to 10\% (Figure 1A). Thus, and to have more buds, the use of BAP alone is desirable.

\subsection{Quadratic effect of BAP on caulogenesis.}

Response surface shows the quadratic effect of BAP where the maximum response is $43 \%$ of caulogenesis in a range of $1.5-3.2 \mathrm{mg} / \mathrm{L}$ of BAP. This percentage may drop to $20 \%$, with concentrations ranging from $0-0.7 \mathrm{mg} / \mathrm{L}$ of BAP (Figure $1 \mathrm{~B}$ ).
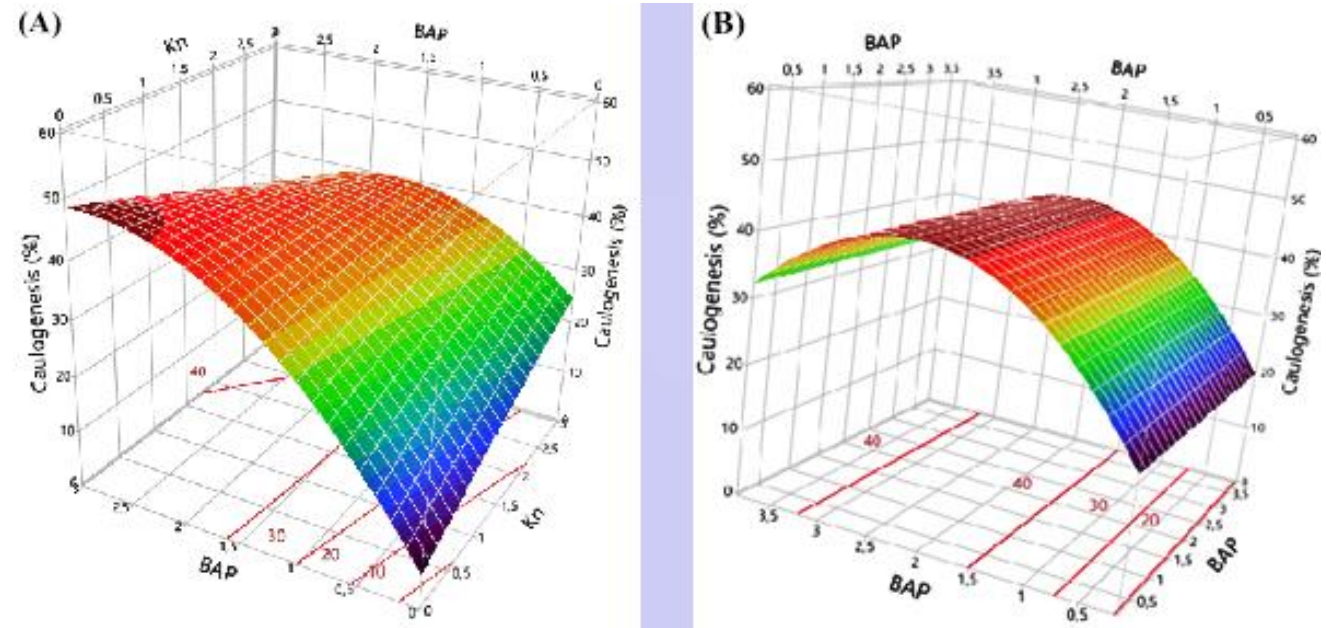

Figure 1. Response surface of caulogenesis induction for C. sativus. 


\subsubsection{Pareto diagram.}

Pareto diagram allowed to visualize the importance of various combinations used in form of a hierarchy. The cumulative effect offered $100 \%$ of the response in caulogenesis, whose BAP alone has $22 \%$ (Figure 2). However, $\mathrm{BAP}^{2}$ combination decreases the response by $15 \%$. We could conclude that the excess of this phytohormone in culture medium negatively affects the caulogenesis. Therefore, the use of these phytohormones in moderation will be desirable.

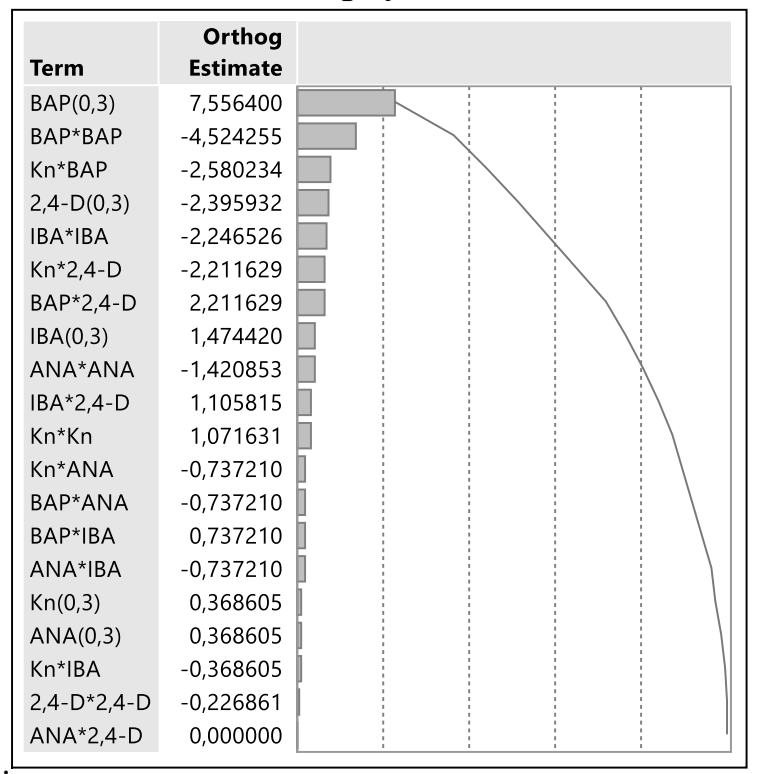

Figure 2. Pareto diagram of caulogenic response for C. sativus

\subsubsection{Callogenesis.}

\subsubsection{Effect testing.}

Effects test analysis predicts the contribution of different phytohormones used for buds induction (Table 8). Only the interaction between two auxins (ANA and 2,4-D) is significant, with a p-value equal 0.040 .

Model coefficients are shown in Table 7 allowed to define the quadratic model, which summarizes all tests representing $C$. sativus callogenesis:

Eq (A.4) $\quad \mathrm{Y}=10+2.187\left(\mathrm{X}_{1}\right)-6.562\left(\mathrm{X}_{2}\right)+5.312\left(\mathrm{X}_{3}\right)+1.25\left(\mathrm{X}_{4}\right)+6.562\left(\mathrm{X}_{5}\right)-10\left(\mathrm{X}_{1} \mathrm{X}_{2}\right)+$ $8.750\left(\mathrm{X}_{1} \mathrm{X}_{3}\right)-1.250\left(\mathrm{X}_{2} \mathrm{X}_{3}\right)+6.250\left(\mathrm{X}_{1} \mathrm{X}_{4}\right)-5\left(\mathrm{X}_{2} \mathrm{X}_{4}\right)+7.5\left(\mathrm{X}_{3} \mathrm{X}_{4}\right)-6.25\left(\mathrm{X}_{1} \mathrm{X}_{5}\right)-7.5\left(\mathrm{X}_{2} \mathrm{X}_{5}\right)-$ $16.25\left(\mathrm{X}_{3} \mathrm{X}_{5}\right)-1.25\left(\mathrm{X}_{4} \mathrm{X}_{5}\right)+2.5\left(\mathrm{X}_{1}^{2}\right)+5\left(\mathrm{X}_{2}^{2}\right)+6.667\left(\mathrm{X}_{3}^{2}\right)+4.583\left(\mathrm{X}_{4}^{2}\right)+2.5\left(\mathrm{X}_{5}^{2}\right)$.

The simplified equation is as follows:

$$
\text { Eq (A.5) } Y=10-16.25\left(X_{3} X_{5}\right)
$$

Table 8. Effect of experimental model coefficients on callogenesis.

\begin{tabular}{c|c|c|c|c} 
Term & Estimate & Std Error & t Ratio & Prob $>|\mathbf{t}|$ \\
\hline Intercept & 10 & 6,131657 & 1,63 & 0,1155 \\
\hline Kn(0,3) & 2,1875 & 3,754858 & 0,58 & 0,5654 \\
\hline BAP(0,3) & $-6,5625$ & 3,754858 & $-1,75$ & 0,0928 \\
\hline ANA(0,3) & 5,3125 & 3,754858 & 1,41 & 0,1695 \\
\hline IBA(0,3) & 1,25 & 3,754858 & 0,33 & 0,7420 \\
\hline $2,4-D(0,3)$ & 6,5625 & 3,754858 & 1,75 & 0,0928 \\
\hline Kn*BAP & -10 & 7,509716 & $-1,33$ & 0,1950 \\
\hline Kn*ANA & 8,75 & 7,509716 & 1,17 & 0,2550 \\
\hline BAP*ANA & $-1,25$ & 7,509716 & $-0,17$ & 0,8691 \\
\hline Kn*IBA & 6,25 & 7,509716 & 0,83 & 0,4131 \\
\hline BAP*IBA & -5 & 7,509716 & $-0,67$ & 0,5116 \\
\hline ANA*IBA & 7,5 & 7,509716 & 1,00 & 0,3275
\end{tabular}




\begin{tabular}{c|c|c|c|c} 
Term & Estimate & Std Error & t Ratio & Prob $>|\mathbf{t}|$ \\
\hline $\mathrm{Kn} * 2,4-\mathrm{D}$ & $-6,25$ & 7,509716 & $-0,83$ & 0,4131 \\
\hline BAP*2,4-D & $-7,5$ & 7,509716 & $-1,00$ & 0,3275 \\
\hline ANA*2,4-D & $-16,25$ & 7,509716 & $-2,16$ & $0,0402 *$ \\
\hline IBA*2,4-D & $-1,25$ & 7,509716 & $-0,17$ & 0,8691 \\
\hline Kn*Kn & 2,5 & 5,084102 & 0,49 & 0,6272 \\
\hline BAP*BAP & 5 & 5,084102 & 0,98 & 0,3348 \\
\hline ANA*ANA & 6,6666667 & 5,084102 & 1,31 & 0,2017 \\
\hline IBA*IBA & 4,5833333 & 5,084102 & 0,90 & 0,3759 \\
\hline 2,4-D*2,4-D & 2,5 & 5,084102 & 0,49 & 0,6272
\end{tabular}

3.3.2.2. Evaluation of phytohormones effects.

This study showed variability of explant responses according to the combination of the hormones used (Figure 2). Some explants showed buds formation while others formed callus.
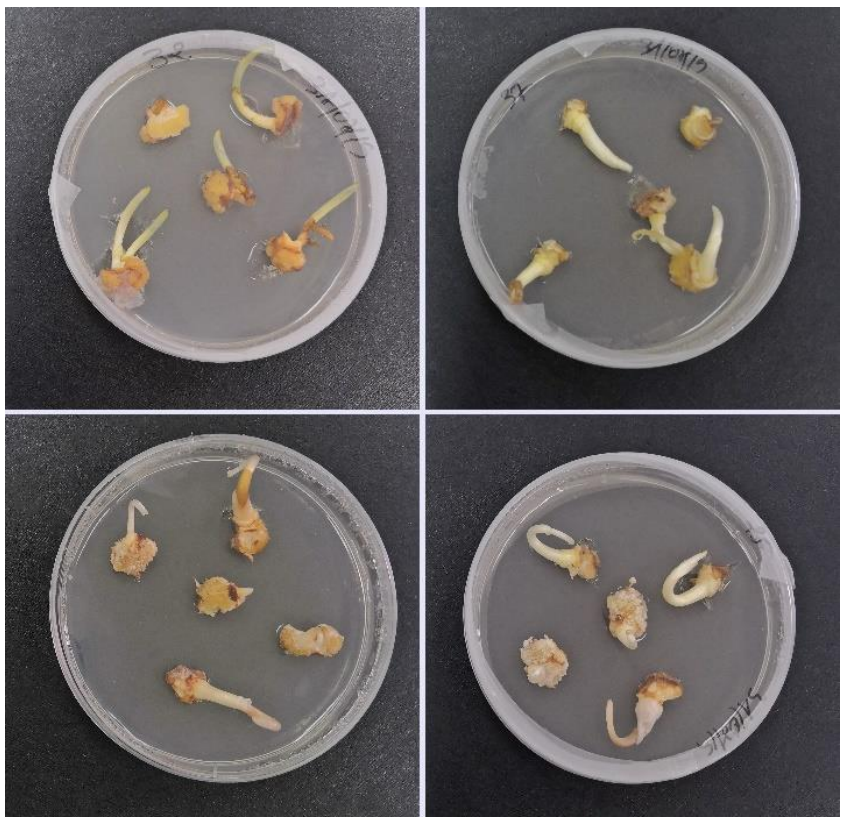

Figure 2. Callogenesis/caulogenesis induction of $C$. sativus explants.

3.3.2.2.1. Effect of BAP*ANA interaction on callogenesis.

Response surface determines the contribution of BAP and ANA to saffron callogenesis (Figure 3A). Thus, a callogenesis percentage of 35\% can be achieved using a concentration of $3 \mathrm{mg} / \mathrm{L}$ in ANA alone. However, the response can be decreased to $15 \%$ by increasing BAP in the culture medium.

\subsection{Effect of ANA*2.4-D interaction on callogenesis.}

Figure $3 \mathrm{~B}$ shows the effect of interaction between two auxins, ANA and 2,4-D, on callus formation. A maximum response was observed at $3 \mathrm{mg} / \mathrm{L}$ ANA and $0 \mathrm{mg} / \mathrm{L}$ 2,4-D or 3 $\mathrm{mg} / \mathrm{L} \mathrm{2,4-D}$ and $0 \mathrm{mg} / \mathrm{L}$ ANA. This means that a desirable response is obtained using just one of them. 

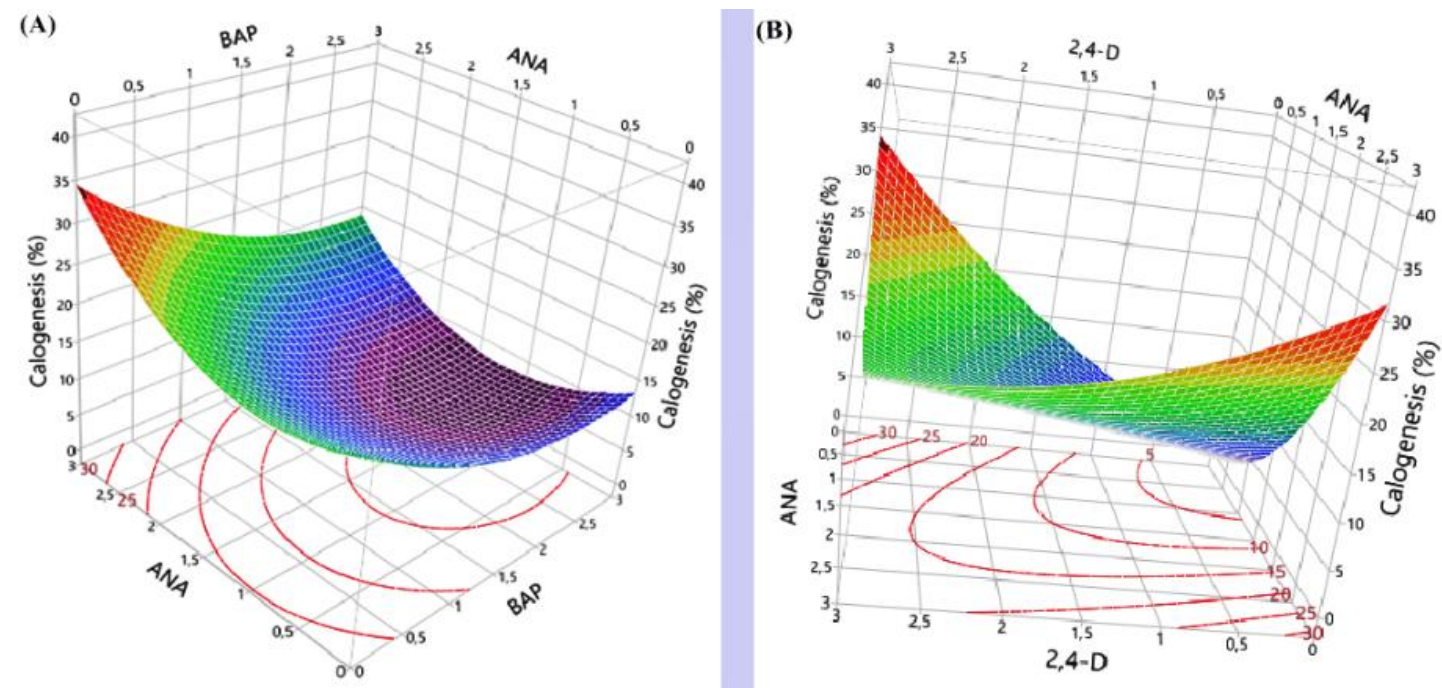

Figure 3. Response surface of callogenesis induction for C. sativus.

\subsubsection{Pareto diagram.}

The figure above presents the Pareto diagram for callogenic response. We constat that ANA*2,4-D decreases the response by $12 \%$, followed by BAP with $10 \%$. In contrast, we found that the use of 2,4-D and ANA separately increases the response by 10 and $8 \%$, respectively. Thus, 2,4-D is more effective for callogenesis induction (Figure 4).

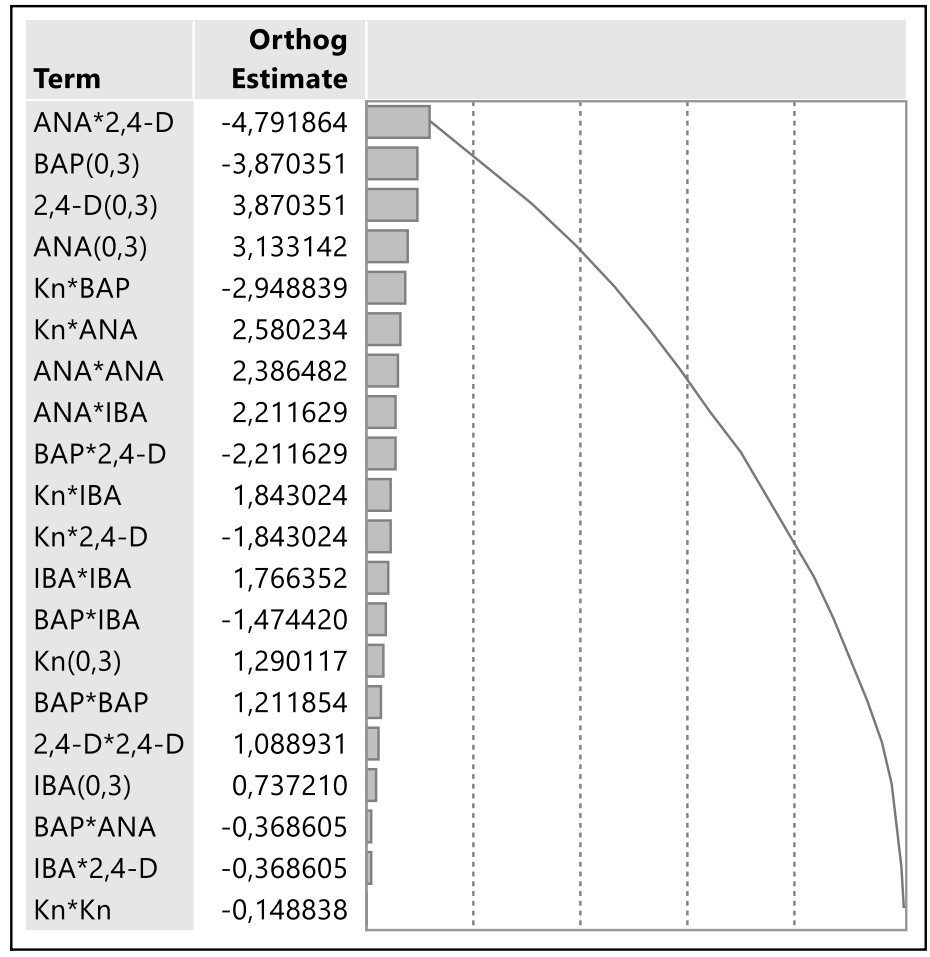

Figure 4. Pareto diagram of the callogenic response for $C$. sativus.

\subsection{Prediction profiler.}

The analysis of results allowed us to establish the prediction profiler of caulogenesiscallogenesis responses (Figure 5). We found that the combination of $3 \mathrm{mg} / \mathrm{L} \mathrm{BAP}+1.056 \mathrm{mg} / \mathrm{L}$ IBA+3 mg/L 2,4-D allows 50\% caulogenesis and 60\% callogenesis. 


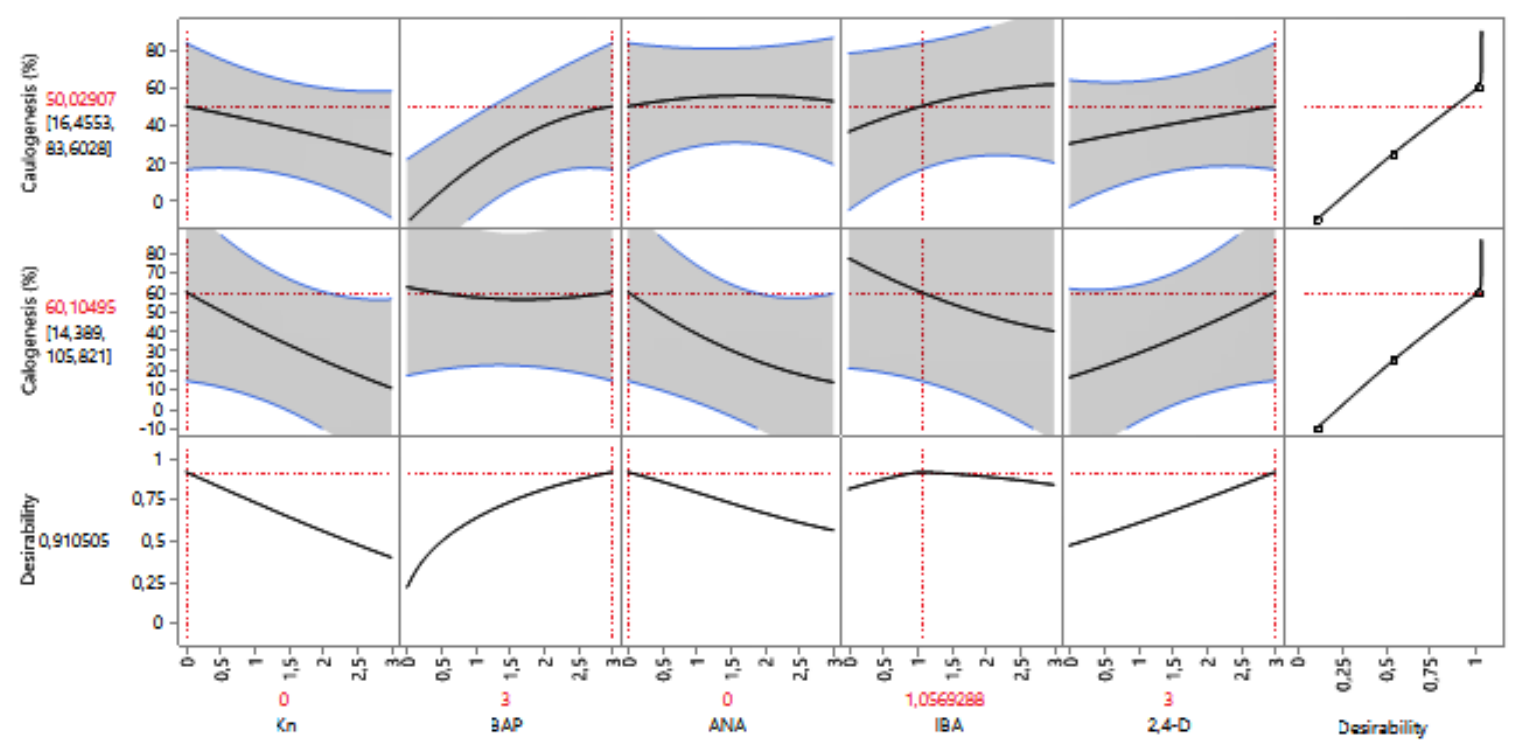

Figure 5. Predictive profiler of the caulogenesis-callogenesis response for $C$. sativus.

Methodology response surface is used in this study to model and optimize caulogenesis and callogenesis induction in Crocus sativus. It can preview phytohormones interaction and predict optimal concentrations of desired response [36-38].

This has been well applied to optimize the production of secondary metabolites in Elaeis guineensis [39] and Pinus sylvestris [40]. Thus, it has been applied to the model, analyze, and optimize the in vitro regeneration of multiple shoots of Citrus sinensis [41] Centella asiatica [42], Basilicum polystachyon [43], Solanum melongena [44], Handroanthus impetiginosus [45], Mucuna pruriens [46], Corylus avellana [47], Gerbera hybrida [48], Lactuca sativa [49], Glycine max [37] and Scoparia dulcis [50].

Our study highlights that the choice and the concentration of phytohormones are very important factors influencing the caulogenesis/callogenesis response of $C$. sativus. The analyses carried out by the experimental Box-Behnken quadratic design have shown that BAP alone allowed for a desirable response in caulogenesis. This finding is confirmed by several studies showing that BAP is the most effective cytokinin for the proliferation of shoots from different explants of saffron $[30,51,52]$.

Results for the study of $C$. sativus caulogenesis allowed us to deduce that concentrations ranging from 1.5 to $3.2 \mathrm{mg} / \mathrm{L}$ are the best for maximum growth using explants of corms. These results agree with those of Lagram et al. [5], indicating that $C$. sativus corms from Taliouine (Morocco) are allowed to have buds using MS medium added with BAP at $1.5 \mathrm{mg} / \mathrm{L}$ from calls. In a similar study, lateral buds of $C$. sativus corms from the Kastamou region (Turkey) favored the formation of shoots in MS medium containing $1.5 \mathrm{mg} / \mathrm{L}$ of BAP [53].

Other researchers, especially, Majourhat et al. [29]; Sarhan et al. [54]; Cavusoglu et al. [55], and Azadi et al. [32] reported that the presence of BAP in the culture medium at concentrations exceeding the range 1.5-3.2 $\mathrm{mg} / \mathrm{L}$ allows $C$. sativus explants to multiply with a good rate and better quality. These results are inconsistent with those of our experiment.

Simona et al. [56] demonstrated that a combination of 2,4-D at $1 \mathrm{mg} / \mathrm{L} \mathrm{BAP}$ at $1 \mathrm{mg} / \mathrm{L}$ is favorable for direct organogenesis from saffron corms and buds. Thus, Lagram et al. [57] found that the best combination for shoot initiation is $2 \mathrm{mg} / \mathrm{L} \mathrm{TDZ}$ with $0.5 \mathrm{mg} / \mathrm{L} \mathrm{NAA}$.

The BAP/NAA ratio seems to be the most critical factor leading to organogenesis or cell dedifferentiation. The absence or presence of IBA, NAA, and BAP at low concentrations results in direct induction of shoots from ovaries as well as from other explants [17,30]. All 
these results are confirmed by other authors revealing the importance of the combined effect of cytokinins and auxins in the formation of shoots in C. sativus [58-62].

The quadratic effect of BAP has shown that an excess of this phytohormone in culture medium causes a drop in response. Studies by Majourhat et al. [29] reported that the newly formed growth of $C$. sativus was inhibited by high concentrations of BAP and TDZ. Several research studies carried out on other plants indicate that high concentrations of BAP lead to growth inhibition and the appearance of morphological alterations for vitroplants [63-66].

Cytokinins are known for stimulating cell division and developing axillary buds by inhibiting apical dominance [67,68]. Thus, culture's success is affected by the type and concentration of cytokinins applied since their absorption, transport, and metabolism differ between varieties, and they can interact with endogenous cytokinins of an explant [69].

Although BAP is a cytokinin commonly used in micropropagation or regeneration systems of medicinal and aromatic plants, it could have several side effects, such as difficulty in rooting, toxicity, and hyperhydricity. This physiological disorder could be due to the imbalance of growth regulators. This phenomenon, in some cases, is associated with the concentration and type of cytokinins [70].

Regarding callus formation, we found that the use of ANA or 2,4-D alone promotes the desired response. Sarhan et al. [54] studied the effect of ANA on callus induction using corms as a source of explants. The results showed that the use of ANA alone improves the production of calluses.

The Pareto diagram obtained in the present study showed that the combination of $\mathrm{Kn}$ and ANA positively affects the callus response. Vatankhah et al. [71] obtained calluses on MS medium containing Kn and ANA and used $C$. sativus corms from Iran as explants. In the same way, Firoozi et al. [72] demonstrated that the highest induction of calluses (100\%) was achieved with corms explants grown on MS medium supplemented with $2 \mathrm{mg} / \mathrm{L}$ ANA and 0.5 $\mathrm{mg} / \mathrm{L} \mathrm{Kn}$.

According to Igarachi and Yuasa [73] MS medium supplemented with 2,4-D combined with BAP causes poor callus induction in $C$. sativus. This is in agreement with the results obtained in our experiment, or we showed that the combination of 2,4-D with ANA, BAP, Kn, and IBA decreases the formation of calluses. However, other research studies have pointed out that the use of auxins in combination with cytokinins (ANA*BAP; ANA*TDZ; 2,4-D*Kn and $2,4-\mathrm{D} * \mathrm{BAP})$ has a promoting effect callus induction and undifferentiated growth using different sources of explants [74-77]. This difference in response is probably due to the genotype of plant material used in various studies [15,78-80].

In the present experiment, the profiler for predicting the caulogenesis-callogenesis response of $C$. sativus shows that a combination of BAP with IBA and 2,4-D gives a response of $50 \%$ of the buds and $60 \%$ of the calli. Growth regulators, especially auxins and cytokinins, play an essential role in controlling plant cell division, growth, and development, and a combination of auxins and cytokinins is primarily necessary to restart proliferation cells in tissue culture $[57,81,82]$.

\section{Conclusions}

Saffron is an aromatic and medicinal plant well known for many pharmacological activities. However, the regeneration of $C$. sativus is confronted with the difficulty of propagation by conventional cuttings. This research study contributed to the in vitro cultivation of $C$. sativus to develop a propagation method of this species. The quadratic Box-Behnken 
experimental protocol was used to calculate the mean response and to study the effects and interactions of different hormones on the induction of caulogenesis and callogenesis in $C$. sativus. The response surface methodology is a tool to study the optimal conditions for the propagation of Crocus sativus using 46 combinations of different hormones. According to our results, the MS medium supplemented with $3 \mathrm{mg} / \mathrm{L}$ of BAP, $1.056 \mathrm{mg} / \mathrm{L}$ of $\mathrm{IBA}$, and $3 \mathrm{mg} / \mathrm{L}$ of 2,4-D allow having a response of $50 \%$ and $60 \%$ of caulogenesis and callogenesis, respectively. The use of this approach has facilitated the induction of caulogenesis /callogenesis of $C$. sativus. Thus, it has allowed identifying important factors for the effects of hormones studied in this research and provides a framework for further investigation.

\section{Funding}

This research received no external funding.

\section{Acknowledgments}

The present work was carried out with the support of the National Scientific and Technical Research Center (CNRST) as part of the Excellence Scholarship program.

\section{Conflict of interest}

The authors declare that there are no conflicts of interest regarding the publication of this paper.

\section{References}

1. Negbi, M.; Saffron cultivation: past, present and future prospects. In: Negbi M (Ed.), Saffron: Crocus sativus L. Harwood Academic Publishers Australia 1999, 18.

2. Plessner, O.; Ziv, M.; Negbi, M. In vitro corm production in the saffron crocus (Crocus sativus L.). Plant Cell Tiss Org Cult 1990, 20, 89-94, https://doi.org/10.1007/BF00114705.

3. Fahim, N.K.; Janati, S.S.F.; Feizy, J. Chemical Composition of Agriproduct Saffron (Crocus Sativus L.) petals and its considerations as animal feed. GIDA 2012, 197-201.

4. Hashemzaei, M.; Mamoulakis, C.; Tsarouhas, K.; Georgiadis, G.; Lazopoulos, G.; Tsatsakis, A.; Asrami, E.S.; Rezaee, R. Crocin: a fighter against inflammation and pain. Food Chem Toxicol 2020, 143, 111521.

5. Lagram, K.; Ben El Caid, M.; El Aaouam, S.; Lachheb, M.; El Mousadik, A.; Serghini, M.A. In Vitro Shoot Regeneration and Development of Microcorms of Moroccan Saffron (Crocus sativus L.). Atlas J Plant Biol 2016, https://doi.org/10.5147/ajpb.2016.0156.

6. Shah, Z.A.; Mir, R.; Matoo, J.M.; Dar, M.A.; Beigh; M.A. Medicinal importance of saffron: A review. $J$ Pharmacog Phytochem 2017, 6, 2475-2478.

7. Nassar, R.; Samar Eid, S.; Chahine, R.; Chabi, B.; Bonnieu, A.; El Sabban, M.; Najjar, F; Hamade L. Antioxidant effects of lebanese Crocus sativus L. and its main components, crocin and safranal, on human skeletal muscle cells. Eur J Integ Med 2020, 40, 101250, https://doi.org/10.1016/j.eujim.2020.101250.

8. Akhondzadeh, S.; Mostafavi, S.A.; Keshavarz, S.A.; Mohammadi, M.R.; Hosseini, S.; Eshraghian, M.R. A placebo controlled randomized clinical trial of Crocus sativus L. (saffron) on depression and food craving among overweight women with mild to moderate depression. J Clin Pharm Therapeut 2020, 45, 134-143.

9. Bakshi, H.A.; Zoubi, M.S.A.; Faruck, H.L.; Aljabali, A.A.A.; Rabi, F.A.; Hafiz, A.A.; Al-Batanyeh, K.M.; Al-Trad, B.; Ansari, P.; Nasef, M.M.; Charbe, N.B.; Satija, S.; Mehta, M.; Mishra, V.; Gupta, G.; Abobaker, S.; Negi, P.; Azzouz, I.M.; Dardouri, A.A.K.; Dureja, H.; Prasher, P.; Chellappan, D.K.; Dua, K.; Da Silva, M.W.; El Tanani, M.; McCarron, P.A.; Tambuwala, M.M. Dietary crocin is protective in pancreatic cancer while reducing radiation-induced hepatic oxidative damage. Nutrients 2020, 12, 1901.

10. Han, S.; Zhuo, Q.; Liu, J.; Da M. Fungal diversity on the surface of saffron corms with different growth characteristics. Plant Biosyst 2020, 155, 1-12, https://doi.org/10.1080/ 11263504.2020.1739163

11. Mirhadi, E.; Nassirli, H.; Malaekeh-Nikouei, B. An updated review on therapeutic effects of nanoparticlebased formulations of saffron components (safranal, crocin, and crocetin). J Pharm Investig 2020, 50, 47-58.

12. Wali, A.F.; Pillai, J.R.; Al Dhaheri, Y.; Rehman, M.U.; Shoaib, A.; Sarheed, O.; Jabnoun, S.; Razmpoor, M.; Rasool, S.; Paray, B.A.; Ahmad, P. Crocus sativus L. extract containing polyphenols modulates oxidative stress and inflammatory response against anti-tuberculosis drugs-induced liver injury. Plants 2020, 9, 167. 
13. Jirage, D.B.; Ravishankar, G.A.; Suvarnalatha, G.; Venkataraman, L.V. Profile of polyamines during sprouting and growth of saffron (Crocus sativus L.) Corms. Plant Growth Regul 1994, 13, 69-72, https://doi.org/10.1007/BF00210949.

14. Chahota, R.K.; Dhiman, K.C.; Rana, S.S.; Mohar, S. Efficacy of different propagating methods for higher daughter corm production in saffron (Crocus sativus L.). Ind Perfumer 2003, 47, 155-158.

15. Devi, K.; Sharma, M.; Singh, M.; Singh Ahuja, P. In vitro cormlet production and growth evaluation under greenhouse conditions in saffron (Crocus sativus L.) -A commercially important crop. Eng Life Sci 2011, 11, 189-194, https://doi.org/10.1002/elsc.201000080.

16. Mir, J.I.; Ahmed, N.; Shafi, W.; Rashid, R.; Khan, M.H.; Sheikh, M.A.; Shah, U.N.; Zaffar, S.; Rathern, I. In vitro development and regeneration of microcorms in saffron (Crocus sativus L.). Afr J Biotechnol 2014, 13, 2637-2640, https://doi.org/10.5897/AJB2013.12831.

17. Darvishi, E.; Zarghami. R.; Mishani, C.A.; Omidi, M. Effects of different hormone treatments on nonembryogenic and embryogenic callus induction and time-term enzyme treatments on number and viability of isolated protoplasts in saffron (Crocus sativus L.). Acta Hortic 2007, 739, 279-284, https://doi.org/10.17660/ActaHortic.2007.739.35.

18. Sukarnih, T.; Rudiyana, Y.; Hanifah, N.F.; Sa'adah, N. Micropropagation of red ginger (Zingiber officinale Rosc. Var. rubrum) using several types of cytokinins. J Phys Conf Ser 2021, 1751, 012051.

19. Minutolo, M.; Chiaiese, P.; Di Matteo, A.; Errico, A.; Corrado, G. Accumulation of ascorbic acid in tomato cell culture: influence of the genotype, source explant and time of in vitro cultivation. Antioxidants 2020, 9, 222, https://doi.org/10.3390/antiox9030222.

20. Z'arate-Salazar, J.R.; de Souza, L.M.; de Morais, M.B.; Neto, L.P.; Willadino, L.; Gouveia- Neto, A.; Ulisses, C. Light-emitting diodes and gas exchange facilitation minimize hyperhydricity in Lippia grata: Physiological, biochemical and morpho anatomical aspects. S Afr J Bot 2020, 135, 164-171, https://doi.org/10.1016/j.sajb.2020.08.019.

21. Kaya, Y.; Huyop, F. An easy and reliable method for establishment and maintenance of tissue cultures of Nicotiana tabacum cv TAPM 26. Int J Sci Lett 2020, 2, 62-71.

22. Mohammed, S. Effects and quantity ranges of some auxins on embryogenic callus induction from upland rice cultivars: An overview. Int J Life Sci Biotechnol 2020, 3, 197-204, https://doi.org/10.38001/ijlsb.669914.

23. Khan, I.; Khan, M.A.; Shehzad, M.A.; Ali, A.; Mohammad, S.; Ali, H.; Alyemeni, M.N.; Ahmad, P. Micropropagation and Production of Health Promoting Lignans in Linum usitatissimum. Plants 2020, 9, 728.

24. Murashige, T.; Skoog, F. A revised medium for rapid growth and bioassays with tobacco tissue cultures. Physiol Plant 1962, 15, 473-497, https://doi.org/10.1111/j.1399-3054.1962.tb08052.x.

25. Tinsson, W. Plans d'expérience : constructions et analyses statistiques: Mathématiques et Applications. Springer Berlin Heidelberg 2010, 114.

26. Montgomery, D.C. Design \& Analysis of Experiments. $6^{\text {th }}$ ed John Wiley\&Sons 2005, ISBN, 978-0-47148735-7.

27. Kiran, B.; Kaushik, A.; Kaushik, C.P. Response surface methodological approach for optimizing removal of $\mathrm{Cr}$ (VI) from aqueous solution using immobilized cyanobacterium. Chem Eng J 2007, 126, 147-153, https://doi.org/10.1016/j.cej.2006.09.002.

28. Rajabpoor, S.H.; Azghandi, A.V.; Saboora, A. Effects of different concentrations of 2,4-D and BAP on somatic embryogenesis induction in saffron (Crocus sativus L.). Pak J Biol Sci 2007, 21, 3927-3930, https://doi.org/10.3923/pjbs.2007.3927.3930.

29. Majourhat, K.; Martínez-Gómez, P.; Fernandez, J.A.; Piqueras, A. Enhanced Plantlet Regeneration from Cultured Meristems in Sprouting Buds of Saffron Corms. Acta Hortic 2007, 739, 275-278, https://doi.org/10.17660/ActaHortic.2007.739.34.

30. Sharma, K.D.; Rathour, R.; Sharma, R.; Goel, S.; Sharma, T.R.; Singh, B.M. In vitro cormlet development in Crocus sativus. Biol Plant 2008, 52, 709-712, https://doi.org/10.1007/s10535-008-0136-y.

31. Guo, B.; Abbasi, B.H.; Zeb, A.; Xu, L.L.; Wei, Y.H. Thidiazuron: a multi-dimensional plant growth regulator. Afr J Biotechnol 2011, 10, 8984-9000, https://doi.org/10.5897/AJB11.636.

32. Goupy, J. Pratiquer les plans d'expériences. Ed DUNOD 2005, Paris.

33. Azadi, P.; Bagheri, K.; Gholami, M.; Masoumi, M.M.; Moradi, A.; Sharafi, A. Thin cell layer, a suitable explant for in vitro regeneration of saffron (Crocus sativus L.). J Agric Sci Technol 2017, 19, 1429-1435.

34. Amini, M.; Younesi, H.; Bahramifar, N.; Lorestani, A.A.Z.; Ghorbani, F.; Daneshi, A.; Sharifzadeh, M. Application of response surface methodology for optimization of lead biosorption in an aqueous solution by Aspergillus niger. J Hazard Mater 2008, 154, 694-702, https://doi.org/10.1016/j.jhazmat.2007.10.114.

35. Kalavathy, M.; Regupathi, H.; Pillai, I.; Miranda, L.R. Modelling, analysis and optimization of adsorption parameters for H3PO4 activated rubber wood sawdust using response surface methodology (RSM). Colloids Surf B Biointerfaces 2009, 70, 35-45, https://doi.org/10.1016/j.colsurfb.2008.12.007.

36. Srivastava, S.; Srivastava, A.K. Statistical medium optimization for enhanced azadirachtin production in hairy root culture of Azadirachta indica. In Vitro Cell Develop Biol-Plant 2012, 48, 73-84, https://doi.org/10.1007/s11627-011-9395y. 
37. Abbasi, Z.; Hooshyar, S.; Bagherieh-Najjar, M.B. Improvement of callus production and shoot regeneration using various organs of soybean (Glycine max L. Merr) by response surface methodology. In Vitro Cell Dev Biol-Plant 2016, 52, 537-545, https://doi.org/10.1007/s11627-016-9778-1.

38. Bansal, M.; Sudhakara Reddy, M.; Kumar, A. Optimization of cell growth and bacoside-a production in suspension cultures of Bacopa monnieri (L.) Wettst. using response surface methodology. In Vitro Cell Dev Biol-Plant 2017, 53, 527-537, https://doi.org/10.1007/s11627-017-9847-0.

39. Gorret, N.; Rosli, S.K.; Oppenheim, S.F.; Willis, L.B.; Lessard, P.A.; Rha, C.; Sinskey, A.J. Bioreactor culture of oil palm (Elaeis guineensis) and effects of nitrogen source, inoculum size and conditioned medium on biomass production. J Biotechnol 2004, 108, 253-263, https://doi.org/10.1016/J.JBIOTEC.2003.12.009.

40. Can, M.Y.; Kaya, Y.; Algur, O.F. Response surface optimization of the removal of nickel from aqueous solution by cone biomass of Pinus sylvestris. Biores Technol 2006, 97, 1761-1765, https://doi.org/10.1016/j.biortech.2005.07.017.

41. Niedz, R.P.; Evens, T.J. Regulating plant tissue growth by mineral nutrition. In Vitro Cell Develop Biol Plant 2007, 43, 370-381, https://doi.org/10.1007/s11627-007-9062-5.

42. Omar, R.; Abdullah, M.A.; Hasan, M.A.; Marziah, M.; Development of growth medium for Centella asiatica cell culture via response surface methodology. Amer $J$ Appl Sci 2004, 1, 215-219, https://doi.org/10.3844/ajassp.2004.215.219.

43. Chakraborty, D.; Bandyopadhyay, A.; Bandopadhyay, S.; Gupta, K.; Chatterjee, A. Use of response surface methodology for optimization of a shoot regeneration protocol in Basilicum polystachyon. In Vitro Cell Dev Biol-Plant 2010, 46, 451-459, https://doi.org/10.1007/s11627-010-9309-4.

44. Naveenchandra, P.M.; Bhattacharya, S.; Ravishankar, G.A. Culture media optimization through Response Surface Methodology for in vitro shoot bud development of Solanum melongena L. for Micropropagation. Int J Bioautom 2011, 15, 159-172.

45. Larraburu, E.E.; Apostolo, N.M.; Llorente, B.E. In Vitro propagation of Pink Lapacho: response surface methodology and factorial analysis for optimisation of medium components. Int J For Res 2012, 2012, 1-9, https://doi.org/10.1155/2012/318258.

46. Sundaram, U.; Anupama, V.; Gurumoorthi, P. Optimization of $\mathrm{pH}$ and sucrose in the callus culture for the micro propagation of Mucuna pruriens using Response Surface Methodology. Int J Pharm Pharmaceut Sci 2013, 5, 420-426.

47. Hand, C.; Reed, B.M. Minor nutrients are critical for the improved growth of Corylus avellana shoot cultures. Plant Cell Tissue Organ Cult 2014, 119, 427-439, https://doi.org/10.1007/s11240-014-0545-x.

48. Niedz, R.P.; Hyndman, S.E.; Evens, T.J.; Weathersbee, A.A. Mineral nutrition and in vitro growth of Gerbera hybrida (Asteraceae). In Vitro Cell Develop Biol Plant 2014, 50, 458-470, https://doi.org/10.1007/s11627014-9620-6.

49. Gomez-Montes, E.O.; Oliver-Salvador, C.; Duran-Figueroa, N.; Badillo-Corona, J.A.; Salas, C.E. Optimization of direct shoot regeneration using cotyledonary explants and true leaves from lettuce cv. Romaine (Lactuca sativa L.) by surface response methodology. Plant Growth Regul 2015, 77, 327-334, https://doi.org/10.1007/s10725-015-0067-5.

50. Premkumar, G.; Karuppanapandian, T.; Sureshpandian, C.; Arumugam, N.; Selvam, A.; Rajarathinam, K. Optimization of a liquid culture system for shoot regeneration and achieving an enriched level of scopadulcic acid b in the leaf organ cultures of Scoparia dulcis L. by Response Surface Methodology. In Vitro Cell Develop Biol Plant 2020, 56, 60-71. https://doi.org/10.1007/s11627-019-10037-z

51. Piqueras, A.; Fernandez, J.A. Phase Change from Dormancy to Continuous Shoot Proliferation in Cultured Meristems of Saffron Corms. In Vitro Cell Develop Biol-Animal 2004, 40, 74.

52. Kashtwari, M.; Aijaz, A.; Wani, A.A.; Dhar, M.K.; Jan, S.; Kamili, A.N. Development of an efficient in vitro mutagenesis protocol for genetic improvement of saffron (Crocus sativus L.). Physiol Mol Biol Plants 2018, 24, 951-962, https://doi.org/10.1007/s12298-018-0576-6.

53. Zeybek. E.; Önde, S.; Kaya, Z. Improved in vitro micropropagation method with adventitious corms and roots for endangered saffron. Centr Eur J Biol 2012, 7,138-145, https://doi.org/10.2478/s11535-011-0102-0.

54. Sarhan, A.Z.; Habib, A.M.; Refaat, A.M.; Awadalla, S.S.A. Comparative effects of BAP and NAA on explant development of micropropagated saffron (Crocus sativus L) corms. J App Sci Res 2013, 9, 5141-5145.

55. Cavusoglu, A.; Sulusoglu, M.; Erkal, S. Plant regeneration and corm formation of saffron (Crocus sativus L.) in vitro. Res J Biotechnol 2013, 8, 128-133.

56. Simona, L.; Cerasela, P.; Florina, F.; Lazar, A.; Giancarla, V.; Danci, M.; Maria, B. In vitro regeneration of Crocus sativus L. J Hortic Sci Biotechnol 2013, 17, 244-247.

57. Lagram, K.; Ben El Caid, M.; Atyane, L.H.; Salaka, L.; El Boullani, R.; El Mousadik, A.; Serghini, MA.; In vitro shoots and micro-corms formation through indirect organogenesis of Moroccan saffron (Crocus sativus L.). Acta Hortic 2017, 1184, 97-108, https://doi.org/10.17660/ActaHortic.2017.1184.14.

58. Bhagyalakshmi, N. Factors influencing direct shoot regeneration from ovary explants of saffron. Plant Cell Tiss Organ Cult 1999, 58, 205-211, https://doi.org/10.1023/A:1006398205936.

59. Ebrahimzadeh, H.; Karamian, R.; Noori-Daloii, M.R. Somatic embryogenesis and regeneration of plantlet in saffron, Crocus sativus L. J. Sci. Islam. Repub. Iran 2000, 11, 169-173. 
60. Chaloushi, B.; Zarghami, R.; Abd-Mishani, C.; Omidi, M.; Agayev, Y.M.; Pakdaman Sardood, B. Effects of different hormonal treatments on the callus production and plantlet regeneration in saffron (Crocus sativus L.). Pak J Biol Sci 2007, 10, 1625-1631, https://doi.org/10.3923/pjbs.2007.1625.1631.

61. Blazquez, S.; Olmos, E.; Hernández, J.A.; Fernández-García, N.; Fernández, J.A.; Piqueras, A. (Somatic embryogenesis in saffron (Crocus sativus L.). Histological differentiation and implication of some components of the antioxidant enzymatic system. Plant Cell Tiss Organ Cult 2009, 97, 49-57, https://doi.org/10.1007/s11240-009-9497-y.

62. Sharifi, G.; Ebrahimzadeh, H.; Ghareyazie, B.; Karimi, M. Globular embryo-like structures and highly efficient thidiazuron-induced multiple shoot formation in saffron (Crocus sativus L.). In Vitro Cell Develop Biol-Plant 2010, 46, 274-280, https://doi.org/10.1007/s11627-009-9264-0.

63. Echeverrigaray, S.; Basso, R.; Andrade, L.B. Micropropagation of Lavandula dentata from axillary buds of field-grown adult plants. Biol Plant 2005, 49, 439-442, https://doi.org/10.1007/s10535-005-0024-7.

64. Saïdi, R.; El bouzdoudi, B.; Kbiach, M.B.; Lamarti, A.; Maouni, A. Effects of macroelements and auxins on the micropropagation of Carob tree (Ceratonia siliqua L., Leguminosae) by shoot tip cultures. J Mater Environ Sci 2015, 6, 2330-2337.

65. Torres-Silva, G.; Resende, S.V.; Lima-Brito, A.; Bezerra, H.B.; De Santana, J.R.F.; Schnadelbach, A.S. In vitro shoot production, morphological alterations and genetic instability of Melocactus glaucescens (Cactaceae), an endangered species endemic to eastern Brazil. S Afr J Bot 2018, 115, 100-107. https://doi.org/10.1016/j.sajb.2018.01.001.

66. Fallah, M.; Farzaneh, M.; Yousefzadi, M.; Ghorbanpour, M.; Mirjalili, M.H. In vitro mass propagation and conservation of a rare medicinal plant, Zhumeria Majdae Rech.f \& Wendelbo (Lamiaceae). Biocatal Agric Biotechnol 2019, 17, 318-325, https://doi.org/10.1016/j.bcab.2018.12.010.

67. Auge, R.; Beauchesne, G.; Boccon-Gibod, J.; Decourtye, L.; Diagat, B.; Jalouzoui, R.; Minier, R.; Morander, C.l.; Reynourd, P.; Strullud, G.; Vidali, H. La culture in vitro et ses applications horticoles, $3^{\mathrm{e}}$ ed : Lavoisier 1989, 225.

68. Margara, F. Bases de multiplication végétative : le méristème et l'organogénèse. INRA Paris France 1989, 262.

69. Werbrouck, S.P.O.; Strnad, M.; Van Onckelen, H.A.; Debergh, P.C. Meta-topolin, an alternative to benzyladenine in tissue culture?. Physiol Plant 1996, 98, 291-297, https://doi.org/10.1034/j.13993054.1996.980210.x.

70. Kataeva, N.V.; Alexandrova, I.G.; Butenko, R.G.; Dragavtceva, E.V. Effect of applied and internal hormones on vitrification and apical necrosis of different plants cultured in vitro. Plant Cell Tiss Organ Cult 1991, 27, 149-154, https://doi.org/10.1007/BF00041283.

71. Vatankhah, E.; Niknam, V.; Ebrahimzadeh, H. Activity of antioxidant enzyme during in vitro organogenesis in Crocus sativus. Biol Plant 2010, 54, 509-514, https://doi.org/10.1007/s10535-010-0089-9.

72. Firoozi, B.; Zare, N.; Sofalian, O.; Sheikhzade-Mosadegh, P. In Vitro Indirect Somatic Embryogenesis and Secondary Metabolites Production in the Saffron: Emphasis on Ultrasound and Plant Growth Regulators. $J$ Agric Sci 2018, 25, 1-10, https://doi.org/10.15832/ankutbd.538973.

73. Igarashi, Y.; Yuasa, M. Effects of $\mathrm{NH}^{4+}$ and total nitrogen content in culture medium on shoot regeneration from calli in saffron (Crocus sativus L.). Plant Tissue Cult Lett 1994, 11, 61-64.

74. Castellar, M.R.; Iborra, J.L. Callus Induction from Explants of Crocus sativus. J Plant Biochem Biot 1997, 6, 97-100, https://doi.org/10.1007/BF03263018.

75. Kareem, M.; Nabi, B.; Kashtwari, M.; Wani, A.A.; Dhar, M.K. Preliminary Report on Development of Proper Stigmas and Stigma-Like Structures in Saffron Under In Vitro Conditions. Proc Natl Acad Sci India 2018, 89, 1213-1217, https://doi.org/10.1007/s40011-018-1037-2.

76. Halim, R.; Akyol, B.; Gürel, A; Bayraktar, M. In Vitro Callus Induction of Saffron (Crocus Sativus L.). Inter J Inno Sci Res Technol 2018, 3, 696-700.

77. Moradi, A.; Zarinkamar, F.; Caretto, S.; Azadi, P. Influence of thidiazuron on callus induction and crocin production in corm and style explants of Crocus sativus L. Acta Physiol Plant 2018, 40, 185, https://doi.org/10.1007/s11738-018-2760-2.

78. Milyaeva, E.L.; Azizbekova, N.S.; Komarova, E.N.; Akhundova, D.D. In vitro formation of regenerant corms of saffron crocus (Crocus sativus L.). Russ J Plant Physiol 1995, 42, 112-119.

79. Venkatachalam, P.; Jiayabalan, N. Effect of auxins and cytokinins on efficient plant regeneration and multipleshoot formation from cotyledons and cotyledonary-node explants of groundnut (Arachis hypogaea L.) by in vitro culture technology. App Biochem Biotechnol 1997, 67, 237-247, https://doi.org/10.1007/BF02788801.

80. Guo, X.F.; Fu, X.L.; Zang, D.K.; Ma, Y. Effect of auxin treatments, cuttings' collection date and initial characteristics on Paeonia 'Yang Fei Chu Yu' cutting propagation. Sci Hortic 2009, 119, 177-181, https://doi.org/10.1016/j.scienta.2008.07.022.

81. Verma, S.K.; Das, A.K.; Cingoz, G.S.; Uslu, E.; Gurel, E. Influence of nutrient media on callus induction, somatic embryogenesis and plant regeneration in selected Turkish crocus species. Biotechnol Rep 2016, 10, 66-74, https://doi.org/10.1016/j.btre.2016.03.006. 